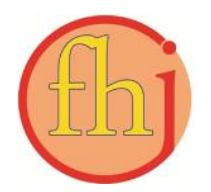

Faletehan Health Journal, 8 (3) (2021) 244-249

www. journal.Ippm-stikesfa.ac.id/ojs/index.php/FHJ

ISSN 2088-673X | e-ISSN 2597-8667

\title{
Konseling WhatsApp Gateway untuk Meningkatkan Kesiapsiagaan Masyarakat dalam Menghadapi Covid-19
}

\author{
Riris Andriati ${ }^{1}$, Fenita Purnama Sari Indah ${ }^{1 *}$, Andiyan $^{2}$, Marta Desri Ayu ${ }^{1}$ \\ ${ }^{1}$ STIKes Widya Dharma Husada Tangerang \\ ${ }^{2}$ Universitas Faletehan \\ *Correspondence Author: fenita.purnama@masda.ac.id
}

\begin{abstract}
Abstrak
Sampai 31 Maret 2020, Indonesia melaporkan 1.528 kasus terkonfirmasi C dengan 136 kematian dan tingkat kematian (case fatality rate) 8,9\%. Pandemi Covid-19 membuat aktifitas menjadi serba terbatas, tidak terkecuali dengan penyebaran informasi sehingga edukasi intensif dibutuhkan untuk membentuk kesiapsiagaan masyarakat. Tujuan penelitian ini adalah untuk mengetahui pengaruh konseling melalui WhatsApp terhadap kesiapsiagaan masyarakat Villa Pamulang Depok dalam menghadapi Covid-19. Penelitian ini menggunakan metode quasi experiment yang bersifat analitik dan one group pretest-posttest design. Sampel dalam penelitian ini berjumlah 44 orang yang diperoleh dengan teknik proportional sample. Responden diberikan edukasi melalui WhatsApp selama 14 hari. Pengaruh penyebaran informasi melalui WhatsApp diukur dengan menggunakan paired sampel $t$-test. Hasil penelitian menunjukkan adanya hubungan antara penyebaran informasi Covid-19 melalui WhatsApp terhadap kesiapsiagaan masyarakat Villa Pamulang Depok dalam mengahadapi Covid-19 dengan $p$-value=0,004. Hasil penelitian juga menunjukkan perbedaan kesiapsiagaan Covid-19 sebelum dan sesudah pemberian informasi Covid-19 melalui WhatsApp. Penelitian ini diharapkan dapat menambahkan pengetahuan terhadap kesiapsiaagan masyarakat sebagai upaya pencegahan Covid19.
\end{abstract}

Kata Kunci: Covid-19, Kesiapsiagaan Masyarakat, Whatsapp Gateway

\section{WhatsApp Gateway Counseling to Increase Community Preparedness in Facing Covid-19}

\begin{abstract}
As of March 31, 2020, Indonesia reported 1,528 confirmed Covid-19 cases with 136 deaths and a case fatality rate (CFR) of $8.9 \%$. Covid-19 pandemic limited activities, including the dissemination of information; thus, an intensive education was required to build community preparedness. The purpose of this study was to identify the effects of counseling through WhatsApp on the preparedness of Villa Pamulang Depok community in dealing with Covid-19. This study used an analytical quasi-experimental method and a one-group pretest-posttest design method. The samples of this study amounted to 44 people who were selected by proportional sample technique. The respondents received education via WhatsApp for 14 days. The effects of information dissemination through WhatsApp was measured by using paired sample t-test. The results of this study showed that there was a relationship between the spread of Covid-19 information via WhatsApp on the community preparedness at Villa Pamulang Depok in facing Covid-19 with p-value 0.004. The findings also showed the difference of Covid-19 preparedness before and after providing information about Covid-19 through WhatsApp. This research was expected to enrich knowledge of community preparedness as an effort of Covid19 prevention.
\end{abstract}

Keywords: Covid-19, Community Preparednes, Whatsapp Gateway 
Faletehan Health Journal, 8 (3) (2021) 244-249

www. journal.Ippm-stikesfa.ac.id/ojs/index.php/FHJ

ISSN 2088-673X | 2597-8667

\section{Pendahuluan}

Sebuah kasus pneumonia misterius pertama kali ditemukan di Wuhan, Provinsi Hubei, China pada Desember 2019. Sampai akhirnya pada 18 Desember hingga 29 Desember ditemukan 5 pasien yang dirawat dengan Acute Respitatory Syndrome (ARDS)(Sulistiani \& Kaslam, 2020;Wulandari, 2020; Muqorobin, 2021). Pada awalnya, penyakit ini dinamakan sementara sebagai 2019 novel corona virus (2019-nCoV), kemudian pada 11 Februari 2020 World Health Organization (WHO) mengumumkan nama baru yaitu Coronavirus Disease (Covid-19) yang disebabkan oleh virus Serve Acute Respitatory Syndrome Coronavirus-2 (SAR-CoV-2) (Susilo et al., 2020). Total kasus terkonfrimasi di dunia pada tanggal 31 Maret 2020 dilaporkan sebanyak 719.758 dengan 33.673 kematian. Adapun sampai 31 Maret 2020, Indonesia sudah melaporkan 1.528 kasus terkonfirmasi dengan 136 kematian dan CFR 8,9\% (Setiati \& Azwar, 2020).

World Health Organization (WHO) mengeluarkan pedoman sementara sesuai dengan International Health Regulation 2005 (IHR 2005) mengenai pedoman surveilans dan respons, diagnosis laboratorium, pencegahan, pengendalian infeksi, manajemen klinis, perawatan pasien dengan suspect Coronavirus Disease (Covid-19), komunikasi risiko serta pemberdayaan masyarakat (Dewiyuliana, D., \& Septiana, 2021). Pemerintah Indonesia telah melakukan berbagai cara untuk mencegah penyebaran virus Covid-19 guna memutus rantai penyebaran virus Covid-19 (Coronavirus Diasease). Upaya tersebut yaitu mensosialisasikan aturan social distancing, menghindari kerumunan, tidak melakukan kontak langsung dengan orang lain, mengenakan masker, mencuci tangan menggunakan sabun dan air mengalir atau hand sanitizer, tidak menyentuh area wajah sebelum mencuci tangan dan menerapkan etika batuk dan bersin yang baik (Kementerian Kesehatan RI, 2020). Upaya tersebut kemudian lebih dikenal dengan Protokol Kesehatan. Riset membuktikan bahwa dengan adanya protokol kesehatan mampu menurunkan dan mencegah penularan virus Covid-19. Penelitian Sari menyebutkan bahwa pengetahuan responden tentang $3 \mathrm{M}$ setelah pemberian materi dan tanya jawab lebih tinggi dibandingkan sebelum diberi penyuluhan. Penelitian menunjukkan bahwa terjadi peningkatan pengetahuan peserta sebesar $44,1 \%$ setelah diberikan penyuluhan (Sari, et al, 2021). Hasil penelitian terdahulu juga menyebutkan bahwa terdapat peningkatan praktik mencuci tangan secara signifikan setelah diberikan intervensi dibandingkan sebelum diberikan intervensi (Hermawati, et al, 2021).

Virus Covid-19 telah dianggap sebagai bencana nasional sehingga semua elemen masyarakat perlu bersatu padu untuk mengurangi serta mencegah penularannya. Oleh karenanya diperlukan kesiapsiagaan masyarakat dalam mencegah bencana penularan virus Covid-19 agar tidak semakin meluas. Kesiapsiagaan merupakan kegiatan yang dilakukan guna mengantisipasi bencana melalui penyelenggaran dan langkah langkah efektif serta efisien agar dapat mengurangi dampak buruk bencana, termasuk kerusakan fisik ataupun korban jiwa. Kesiapsiagaan Covid-19 dalam upaya menghadapi ancaman Covid-19 (Coronavirus Disease) ataupun penyakit dan faktor risiko kesehatan yang berpotensi Kedaruratan Kesehatan Masyarakat (KKM) lainnya, terdiri dari kesiapsiagaan Sumber Daya Manusia (SDM) dan peningkatan sarana prasarana (Nelwan, 2020). Peningkatan kapasitas SDM dalam kesiapsiagaan menghadapi Covid-19 (Coronavirus Disease) dengan melakukan pelatihan, tabletop exercise, dan simulasi penanggulangan Covid-19 (Coronavirus Disease). Thaha, et al, menjelaskan hal - hal yang diperlukan dalam kesiapsiagaan bencana ialah pengetahuan mengenai mitigasi bencana serta ketentuaanya, edukasi mengenai kebencanaan dalam bentuk sosialisasi, pelatihan, serta pendidikan formal, tanggap bencana, dan sistem peringatan dini (Thaha, 2020). Penelitian menunjukkan adanya hubungan antara pengetahuan, sikap dengan kesiapsiagaan terhadap Covid-19 (Thaha et al., 2020). Penyebaran penyakit Covid-19 sangat cepat sehingga dapat menyebabkan penyebaran kasus yang sangat luas dan membunuh banyak orang sehingga diperlukan persiapan dan kewaspadaan masyarakat terhadap penyakit ini. Individu yang menunjukkan tanda dan gejala dari penyakit coronavirus dapat melakukan isolasi mandiri dan pemenuhan kebutuhan sehari-harinya dilakukan oleh keluarga dan masyarakat. Adanya kesiapsiagaan masyarakat terhadap pencegahan penyakit ini dapat mengendalikan penyebaran dari penyakit coronavirus. Untuk meningkatkan kesiapsiagaan masyarakat tersebut, maka perlu dilakukan upaya 
edukasi secara intensif. Upaya edukasi yang dirasa paling tepat pada kondisi pandemik saat ini adalah menggunakan teknologi internet dengan berbagai aplikasi sosial yang disediakan. Penggunaan teknologi internet dalam kegiatan edukasi selain dapat menjangkau sasaran yang lebih luas, cepat juga membantu program pemerintah dalam pencegahan dan penularan virus Covid-19. Bedasarkan hal tersebut, maka perlu diupayakan solusi yang dapat memanfaatkan penggunaan teknologi dalam penyebaran edukasi intensif, misalnya dengan memanfaatkan aplikasi WA (Whatssapp). Aplikasi Whatssapp dipilih karena sebagian besar masyarakat Indonesia menggunakan media sosial Whatsapp (Fatmawati et al., 2020).

Hingga 31 Maret 2020, Indonesia sudah melaporkan 1.528 kasus terkonfirmasi dengan 136 kematian dan CFR 8,9\%. Daerah Jabodetabek menjadi titik utama dari kasus penderita dan korban karena Covid-19 (Coronavirus Diasease). Adapun jumlah kasus Covid-19 terkonfirmasi di Kota Depok pada tanggal 18 Mei 2021 yaitu 1.025 dengan kematian 936 (Dinas Kesehatan Depok, 2021). Penelitian dilakukan pada Villa Pamulang, Kelurahan Pondok Petir, Kecamatan Bojongsari Kota Depok. Wilayah tersebut melakukan micro lockdown lantaran belasan warga terpapar Covid-19. RT 01 Villa Pamulang terdapat sebanyak 18 warga terpapar Covid-19 dan sedang menjalani isolasi mandiri (Isoman) di rumah masing-masing. Warga yang terpapar virus Covid-19 rata-rata masih usia produktif dan satu lansia yang tertular dari klaster perkantoran ke keluarga. Para warga yang terpapar diketahui setelah dilakukan tes swab Antigen dan PCR hasilnya positif Covid-19 (Poskota, 2021).

Hasil studi pendahuluan yang dilakukan peneliti kepada sepuluh warga Villa Pamulang Depok pada tanggal 20 April 2021, diketahui bahwa terdapat 20 masyarakat yang dinyatakan positif Covid-19, 5 orang diantaranya meninggal dunia dan lainnnya dinyatakan sembuh. Berdasarkan hasil studi pendahuluan tersebut maka peneliti tertarik untuk melakukan penelitian yang berjudul "Konseling Whatsapp Gateway Terhadap Kesiapsiagaan Masyarakat dalam Menghadapi Covid-19". Tujuan penelitian ini adalah untuk mengetahui perbedaan kesiapsiagaan masyarakat Villa Pamulang Depok dalam menghadapi Covid-19 antara sebelum dan sesudah penyebaran informasi Covid-19 melalui Whatsapp.

\section{Metodologi Penelitian}

Penelitian ini merupakan quasi experiment dengan pendekatan one-group pre test dan post test design. Pre test diberikan terlebih dahulu sebelum diberikan intervensi berupa pemberian informasi melalui Whatsapp selama 14 hari, dimana pemberian informasi dilakukan setiap 2 hari sekali. Setelah diberikan intervensi, kemudian diberikan post test untuk melihat perbedaan antara hasil pre test dan post test responden. Pengumpulan data melalui kuesioner dalam bentuk google form yang diberikan melalui grup Whatsapp. Kuesioner kesiapsiagaan Covid-19 meliputi 12 pertanyaan mengenai kebiasaan mencuci tangan, menggunakan masker ketika keluar rumah, menjaga jarak minimal 1 meter, menghindari kerumunan, melakukan rapid test bila menunjukkan gejala covid, swab test/PCR sesuai dengan kebutuhan dan isolasi mandiri jika menunjukkan tanda dan gejala, memantau masyarakat yang melakukan isolasi mandiri dan penyemprotan pada rumah yang mengalami Covid19, serta membantu dalam memenuhi kebutuhan anggota keluarga yang mengalami Covid-19. Kuesioner diadopsi dari Dewiyuliana, D., \& Septiana, 2020 yang telah diuji validitas dan reliabilitas. Semua pertanyaan dinyatakan valid $(p$ value $>0,05$ dan reliabel dengan nilai Cronbach's alpha $0,672(>0,6)$.

Populasi dalam penelitian ini berjumlah 303 Kepala Keluarga di Villa Pamulang RW 11 terdiri dari RT 01, 02, 03, dan 04 Kota Tangerang Selatan. Penghitungan besar sampel menggunakan rumus Lemeshow dengan $p=0,93$ dan $\mathrm{q}=0,07$ (Dewiyuliana, D., \& Septiana, 2020). Jumlah sampel yang diperoleh sebanyak 44 responden. Penentuan jumlah sampel pada setiap RT dilakukan dengan proportionate sample size. Teknik pengambilan sampel menggunakan accidental sampling pada tiap RT.

Hasil uji normalitas menggunakan Uji Shapiro Wilk terhadap kesiapsiagaan Covid-19 menunjukkan distribusi data normal ( $p$ value > $0,05)$, sehingga uji bivariat yang digunakan adalah Uji T dependen (T-test Paired). Penelitian ini telah dilakukan kaji etik dengan nomor 122/KEPK/FKM-UNEJ/I/2021. Kriteria inklusi penelitian: Kepala Keluarga di Villa Pamulang RW 11 terdiri dari RT 01, 02, 03, dan 04 Kota 
Faletehan Health Journal, 8 (3) (2021) 244-249

www. journal.Ippm-stikesfa.ac.id/ojs/index.php/FHJ

Tangerang Selatan yang bersedia menjadi responden penelitian dan mengikuti intervensi yang dilaksanakan

\section{Hasil dan Pembahasan}

Berikut ini adalah karakteristik responden hasil penelitian:

Tabel 1: Karakteristik Responden $(\mathrm{n}=44)$

\begin{tabular}{lcc}
\hline \multicolumn{1}{c}{ Karakteristik } & n & \% \\
\hline Jenis Kelamin & & \\
$\quad$ Laki-laki & 41 & 93,2 \\
Perempuan & 3 & 6,8 \\
\hline Usia (Tahun) & & \\
$27-35$ & 20 & 45,5 \\
$36-45$ & 15 & 34 \\
$>46$ & 9 & 20,5 \\
\hline Pendidikan & & \\
SD & 1 & 2,3 \\
SMP & 2 & 4,5 \\
SMA/K & 15 & 34 \\
$\quad$ Perguruan Tinggi & 26 & 59 \\
\hline Pekerjaan & & \\
$\quad$ Karyawan & 26 & 59 \\
Guru & 2 & 4,5 \\
Wirausaha & 10 & 22,7 \\
$\quad$ Wiraswasta & 4 & 9,1 \\
Driver & 1 & 2,3 \\
$\quad$ Freelance & 1 & 2,3 \\
\hline Pernah Menderita Covid- & & \\
19 & & \\
$\quad$ Ya & 7 & 16 \\
Tidak & 37 & 84 \\
\hline
\end{tabular}

Tabel 1 dapat diketahui bahwa jenis kelamin mayoritas adalah laki-laki, hampir setengah responden berusia 27-35 tahun (45,5\%) dengan tingkat pendidikan terakhir peling banyak perguruan tinggi (59\%), bekerja sebagai karyawan (59\%) dan tidak pernah menderita Covid-19 $(84 \%)$.

Tabel 2: Kesiapsiagaan Covid-19 Sebelum Penyebaran Informasi Covid-19 Melalui Whatsapp $(\mathrm{n}=44)$

\begin{tabular}{ccccc}
\hline Variabel & Mean & Min & Maks & SD \\
\hline $\begin{array}{c}\text { Pre Test } \\
\text { Kesiapsiagaan } \\
\text { Covid-19 }\end{array}$ & 28 & 21 & 36 & 4,187 \\
\hline $\begin{array}{c}\text { Post Test } \\
\text { Kesiapsiagaan } \\
\text { Covid-19 }\end{array}$ & 29,27 & 20 & 36 & 3,618 \\
\hline
\end{tabular}

Tabel 2 dapat diketahui terjadi peningkatan skor kesiapsiagaan Covid-19, dimana pada saat sebelum dilakukan intervensi didapati nilai ratarata adalah 28, sedangkan pada sesudah intervensi didapati nilai rata-rata meningkat menjadi 29,27.

Tabel 3: Perbedaan Penyebaran Informasi Covid19 melalui Whatsapp terhadap Kesiapsiagaan Covid-19 Masyarakat $(n=44)$

\begin{tabular}{lcc}
\hline \multicolumn{1}{c}{ Variabel } & Mean & Sig. (2-tailed) \\
\hline $\begin{array}{l}\text { Pre test } \\
\text { kesiapsiagaan }\end{array}$ & 28 & \\
$\begin{array}{l}\text { Covid-19 } \\
\text { Post test }\end{array}$ & & \\
$\begin{array}{l}\text { kesiapsiagaan } \\
\text { Covid-19 }\end{array}$ & & 0,004 \\
\hline
\end{tabular}

Tabel 3 menunjukkan terjadi peningkatan kesiapsiagaan Covid-19 dengan $p$ value $=0,004$ artinya terdapat perbedaan kesiapsiagaan Covid-19 sebelum dan sesudah pemberian informasi Covid19 melalui Whatsapp pada masyarakat RW 11 Villa Pamulang Depok.

Whatsapp adalah salah satu sarana diskusi pembelajaran yang efektif, dimana dalam aplikasi Whastapp pengguna dapat berkirim pesan secara instan, serta memungkinkan pengguna untuk saling bertukar gambar, video, pesan suara, serta untuk berbagi informasi dan diskusi (Rahartri, 2019; Muqorobin, 2021). Adapun salah satu upaya pemerintah dalam kesiapsiagaan Covid-19, salah satu diantaranya adalah menyiapkan media komunikasi resiko atau bahan Komunikasi Informasi dan Edukasi (KIE) dan menempatkan bahan KIE tersebut di lokasi yang tepat (Zulfa \& Kusuma, 2020).

Hasil penelitian ini sejalan dengan penelitian sebelumnya yang menunjukkan bahwa terdapat hubungan antara penyebaran informasi Covid-19 melaui Whatsapp dengan kesiapsiagaan masyarakat dalam menghadapi Covid-19 dengan $p$ value $=0,000$. Kesiapan individu dalam kesiapsiagaan bencana ditunjukkan dengan adanya pengetahuan, keterampilan dan kemampuan yang didapatkan melalui pembelajaran dari pengalaman yang diterapkan selama keadaan darurat (Dewiyuliana, D., \& Septiana, 2020). Penggunaan media dapat meningkatkan pengetahuan para pedagang di car free day Temanggung dan 
perilaku dalam upaya menerapkan protokol kesehatan (Wulandari, 2020). Hal ini juga sejalan dengan penelitian yang dilakukan Ferianto \& Hidayati dari hasil penelitiannya menunjukkan bahwa dengan pemberian pengetahuan menggunakan pelatihan dan media dapat meningkatkan perilaku kesiapsiagaan responden. Pelatihan dapat menciptakan interaksi dalam suatu lingkungan adanya kemampuan interkasi antara sesame peserta menjadi kunci dalam memperkaya informasi (Feriyanto \&Hidayati, 2019).

Promosi kesehatan secara massa dapat dilakukan dengan menggunakan media sosial, salah satunya adalah Whatsapp. Dimana Whatsapp menjadi salah satu media sosial yang dapat menjadi sarana pembelajaran yang efektif, pengguna dapat menyebarkan informasi berupa teks, gambar video, pesan suara dan interaksi antar pengguna (Fitriyani, 2017). Dengan bertambahnya informasi yang didapatkan seseorang, bertambah pula pengetahuan yang dimilikinya dimana pengetahuan tersebut dapat meningkatkan perilaku. Pemberian infomasi melalui Whatsapp dapat meningkatkan kesiapsiagaan Covid-19, dimana kesiapsiagaan Covid-19 dipengaruhi oleh pengetahuan serta faktor metode dan media pembelajaran yang tepat. Tidak dapat dipungkiri bahwa perkembangan teknologi memiliki peranan penting dalam mendapatkan suatu informasi, salah satunya dengan adanya media sosial yang mendukung tranformasi pengetahun dan informasi.

\section{Simpulan}

Kesiapsiagaan masyarakat meningkat setelah dilakukannya penyebaran informasi melalui aplikasi Whatsapp. Hal ini berarti bahwa perlu dilakukannya berbagai langkah inovasi yang memanfaatkan sosial media dalam meningkatkan kesiapsiagaan masyarakat sehingga meningkatkan perilaku masyarakat dalam mencegah penularan Covid 19.

\section{Referensi}

Dewiyuliana, D., \& Septiana, N. (2020). Pengaruh Penyebaran Informasi Covid-19 Melalui Whatsapp Terhadap Kesiapsiagaan Masyarakat Dalam Menghadapi Covid-19. Jurnal Ilmiah Permas: Jurnal Ilmiah STIKES Kendal, 11(1), 103-112.

Dinas Kesehatan Depok. (2021). Perkembangan Covid-19 di Kota Depok.
https://dinkes.depok.go.id/User/detail/updatecovid-19-kota-depok-per-18-mei-2021.

Fatmawati, Y. D., Rosyadah, R., Damayanti, M. D., Abigael, D. P., Ismawati, F., Ilmi, A. F., \& Ratnaningtyas, T. O. (2020). Kuliah Whatsapp Dalam Meningkatkan Pengetahuan Ibu Terhadap Pencegahan Stunting Pada Balita Di Masa Pandemi. Jam: Jurnal Abdi Masyarakat, 1(1).

Ferianto, K., \& Hidayati, U. N. (2019). Efektifitas Pelatihan Penanggulangan Bencana Dengan Metode Simulasi Terhadap Perilaku Kesiapsiagaan Bencana Banjir Pada Siswa Sman 2 Tuban. Jurnal Kesehatan Mesencephalon, 5(2).Mesencephalon, $5 \quad$ (2). http://dx.doi.org/10.36053/mesencephalon.v5 i2.110

Fitriani, Y. (2017). Analisis pemanfaatan berbagai media sosial sebagai sarana penyebaran informasi bagi masyarakat. ParadigmaJurnal Komputer dan Informatika, 19(2), 148152.

Henny Syapitri, Laura Mariati Siregar, F. L. S. (2020). Pencegahan Penularan Covid-19 Melalui Sosialisasi Dan Pembagian Masker Di Pasar Pringgan Medan. Jurnal Kreativitas Pengabdian Kepada Masyarakat (PKM), 3(2), 274-282.

Hermawati, B., Handayani, O. W. K., Mahendrasari, D. S., Mukti, F. A., \& Wijayanti, A. (2021). Edukasi Kesehatan Mengenai Praktik Cuci Tangan pada Guru sebagai Upaya Pencegahan Covid-19. Jurnal Obsesi: Jurnal Pendidikan Anak Usia Dini, 6(2), 894-902.

Kementerian Kesehatan RI. (2020). Peraturan Menteri Kesehatan Republik Indonesia Nomor 9 Tahun 2020 Tentang Pedoman Pembatasan Sosial Berskala Besar Dalam Rangka Percepatan Penanganan Corona Virus Disease 2019 (COVID-19). Jakarta.

Muqorobin, N. A. R. R. (2021). Analisis Peran Teknologi Sistem Informasi Dalam Pembelajaran Kuliah Dimasa Pandemi Virus Corona. Proceeding Seminar Nasional \& Call For Papers, (November), 157-168.

Nelwan, J. E. (2020). Surveilans Kesehatan Masyarakat: Suatu Pengantar. Insan Cendekia Mandiri.

Poskota. (2021). Lockdown, Belasan Warga Perumahan Villa Pamulang 
Faletehan Health Journal, 8 (3) (2021) 244-249

Positif Covid-19.

Purnamasari, Ika., \& Rahayrani, A. E. (2020). Tingkat Pengetahuan Dan Perilaku Masyarakat Kabupaten Wonosobo Tentang Covid-19. Jurnal Kesehatan Ilmiah.

Rahartri. (2019). “Whatsapp" Media Komunikasi Efektif Masa Kini (Studi Kasus Pada Layanan Jasa Informasi Ilmiah di Kawasan Puspiptek). Visi Pustaka, 21(2), 147-156.

Sari, D. P., Rahayu, A., Mukti, A. W., \& Suwarso, L. M. (2021). Sosialisasi Kepatuhan Protokol Kesehatan Sebagai Upaya Pencegahan Penularan COVID-19. JMM (Jurnal Masyarakat Mandiri), 5(3), 828-835.

Setiati, S., \& Azwar, M. K. (2020). COVID-19 and Indonesia. (April).

Sulistiani, K., \& Kaslam, K. (2020). Kebijakan Jogo Tonggo Pemerintah Provinsi Jawa Tengah dalam Penanganan Pandemi Covid19. Vox Populi, 3(1), 31. https://doi.org/10.24252/vp.v3i1.14008

Susilo, A., Rumende, C. M., Pitoyo, C. W., Santoso, W. D., Yulianti, M., Herikurniawan, H., ... Yunihastuti, E. (2020). Coronavirus Disease 2019: Tinjauan Literatur Terkini. Jurnal Penyakit Dalam Indonesia, 7(1), 45. https://doi.org/10.7454/jpdi.v7i1.415

Thaha, Ida Leida M. Pratiwi, Indrakasih. Thaha, Adhi Nauval Hafizh. Jaharuddin, A Rinaldy. Yusnitasari, Andini Selvi. Irabuana. Mutmainnah, Lolah Auliya. Qura, U. (2020). Determinan Kesiapsiagaan Pandemi Covid-19 pada Mahasiswa Se-Kota Makassar. Media Kesehatan Masyarakat, 16(4), 461-467.

Wulandari, S. (2020). Journal: Maternity And Neonatal, Vol. 03, No. 02, September 2020. Journal: Maternity and Neonatal, 03(02), 125-131.

Wulandari, T. S., Anisah, R. L., Fitriana, N. G., \& Purnamasari, I. (2020). Pengaruh Pendidikan Kesehatan Dengan Media Leaflet Untuk Meningkatkan Pengetahuan Dan Perilaku Dalam Upaya Menerapkan Protokol Kesehatan Pada Pedagang Di Car Free Day Temanggung. Jurnal Ilmiah Kesehatan,10(2), 6-15.

Zulfa, F., \& Kusuma, H. (2020). Upaya Program Balai Edukasi Corona Berbasis Media Komunikasi dalam Pencegahan Penyebaran Covid-19. Jakp: Jurnal Abdimas Kesehatan Perintis, 2(1), 21-23. 